Article

\title{
Sustainable Organic Corn Production with the Use of Flame Weeding as the Most Sustainable Economical Solution
}

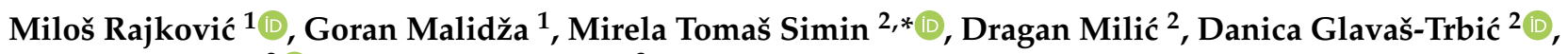 \\ Maja Meseldžija ${ }^{2}$ (1) and Sava Vrbničanin ${ }^{3}$ \\ 1 Institute of Field and Vegetable Crops, Maksima Gorkog 30, 21000 Novi Sad, Serbia; \\ milos.rajkovic@nsseme.com (M.R.); goran.malidza@ifvcns.ns.ac.rs (G.M.) \\ 2 Faculty of Agriculture, University of Novi Sad, Trg Dositeja Obradovića 8, 21000 Novi Sad, Serbia; \\ mdragan@polj.uns.ac.rs (D.M.); danicagt@polj.uns.ac.rs (D.G.-T.); maja@polj.uns.ac.rs (M.M.) \\ 3 Faculty of Agriculture, University of Belgrade, Nemanjina 6, 11080 Belgrade, Serbia; sava@agrif.bg.ac.rs \\ * Correspondence: mirela.tomas@polj.edu.rs; Tel.: +381-62-240-123
}

check for updates

Citation: Rajković, M.; Malidža, G.; Tomaš Simin, M.; Milić, D.;

Glavaš-Trbić, D.; Meseldžija, M.; Vrbničanin, S. Sustainable Organic Corn Production with the Use of Flame Weeding as the Most Sustainable Economical Solution. Sustainability 2021, 13, 572. https:// doi.org/10.3390/su13020572

Received: 30 October 2020 Accepted: 6 January 2021 Published: 9 January 2021

Publisher's Note: MDPI stays neutral with regard to jurisdictional clai$\mathrm{ms}$ in published maps and institutional affiliations.

Copyright: (C) 2021 by the authors. Licensee MDPI, Basel, Switzerland. This article is an open access article distributed under the terms and conditions of the Creative Commons Attribution (CC BY) license (https:// creativecommons.org/licenses/by/ $4.0 /)$.

\begin{abstract}
Flame weeding is an alternative method of weed control. Essentially, it is a supplement to other physical and mechanical processes used in organic production. Weed control costs have a large share of the total cost of crop production. This study aimed to investigate hand weed hoeing's cost-effectiveness, accompanied by inter-row cultivation and flame weeding applied in organic maize production using two different machines to determine the economically best solution. For this purpose, the prototype flame weeder and commercial flame-weeding machinery were used. Designed primarily for smaller fields, the prototype flame weeder was equipped with a cultivator and a $70 \mathrm{~kg}$ propane bottle. Commercial Red Dragon flame weeder, fitted with an $800 \mathrm{~kg}$ propane tank and featuring no cultivation implements, is designed for larger areas. The analysis has shown that hand hoeing produced a higher yield ( $8.3 \mathrm{t} / \mathrm{ha}$ in total), but it contributed significantly to the production costs. The costs per hectare decreased when the prototype flame weeder and the commercial Red Dragon flame weeder were used compared to hand hoeing. More beneficial economic impacts were recorded when the prototype flame weeder was used (489.39€/ha) than in applying the Red Dragon flame weeder ( $456.47 € / \mathrm{ha})$. The efficacy of flame weeding is somewhat limited and could be enhanced by additional hand hoeing, if the effect of the machine in terms of weeding is observed. However, the analysis has shown that, in this case, investments in additional hand hoeing are not economically justified because the operating costs incurred therein $(168 € /$ ha) were not met by a yield increase of $500 \mathrm{~kg} / \mathrm{ha}$, i.e., a surplus revenue of $100 € /$ ha. Moreover, the economic impacts of flame weeding would be considerably more significant in larger fields.
\end{abstract}

Keywords: cost-effectiveness; flame weeding; maize; organic agricultural production

\section{Introduction}

Increased demand for food has altered the methods of agricultural production. "Nowadays, it is obvious that conventional (industrial) methods of agricultural production, in addition to procuring sufficient sustenance and an array of products, precipitate a series of negative not only ecological but also social and economic repercussions" [1]. Hodge [2] summarized specific negative trends in contemporary agriculture, which prompted such production systems' long-term sustainability. He further argued that agriculture is inclined to utilize inputs originating from distant spatial and sectoral sources. Additionally, it consumes increasing energy supplies generated from non-renewable sources. Agriculture depends on a deteriorating genetic base, and it exerts detrimental effects on the environment. All the considerations mentioned above are mainly manifested in (1) a strengthening link between agriculture and the chemical industry (under artificial fertilizers and pesticides), (2) dependence of agriculture on subsidies and price control, and (3) an increasing 
number of grave repercussions affecting habitats, animal and plant species, the environment, and human health and well-being. As part of the socio-economic sub-systems, modern agricultural production has proven adverse effects on the environment [3-5] due to increasing dependence on the industry (in terms of fertilizers and pesticides) and the introduction of monoculture for the sake of profit. The adverse effects of contemporary agricultural production have emphasized the importance of alternative production systems. A different approach to the environment inherently characterizes such systems. Organic agriculture is an alternative production system considered more beneficial to the environment than conventional production systems [1]. Lampkin and Padel [6] define organic agriculture as a philosophy and a production method to create integrated, humane, economically sustainable, and environment-friendly agriculture. Organic agriculture tends to maximize the use of renewable on-farm resources. It represents a system of managing ecological and biological processes to achieve acceptable crop yields, animal gains, and essential nutrient production. Notwithstanding the conceptual differences in organic farming, such a system's primary objective is sustainable agricultural production.

The notion of sustainability is used in a broad sense, encompassing economic, social, and environmental sustainability [7]. Considering that sustainability comprises an economic aspect (among others) [8,9], it is crucial to develop cost reduction methods in organic agriculture, which would exert positive effects on the total financial results. Although organic production requires higher investments, it ultimately results in higher quality products [10]. Farmers are often prompted to convert and conform to an organic farming system by economic sustainability [11-13].

According to some estimates, in conventional agriculture, weed control costs are higher than the costs of disease and pest control put together, and weeds account for a maize yield decrease of $13.2 \%$ worldwide [14]. Weed control is one of the most expensive steps in crop production [15] and is considered one of the main challenges responsible for significantly reducing yields in agricultural farming, especially in organic systems, where weed control is cited as the most critical production problem [15].

Consequently, weed control is of paramount importance to cost-effective maize production. Organic farmers cite weeds as the most severe production problem they encounter, and total crop losses from weeds can occur under the organic system [16].

Farmers often perceive the fear of ineffective weed control as one of the significant obstacles to conversion from conventional to organic farming [17]. Pannacci [18] stated that weed control has a significant effect on maize growth because the competition ability of maize is relatively low at early crop growth stages [18]. Weed control is a challenge in all systems of agricultural production, but it is especially pronounced in organic crop production. The use of herbicides is unallowed $[19,20]$, so weed control is often limited to physical methods where hand weeding and mechanical cultivation are the most popular [21]. Organic producers often utilize hand weeding, but it is expensive, time-consuming, and challenging to organize [22]. Mechanical cultivation is one of the most commonly used weed control practices in row crops. Additionally, it has been reported that cultivation leaves a strip of uncontrolled weeds on either side of the crop row, influencing crop yield [23], and repeated cultivation increases the chance of soil erosion, destroys soil quality, and promotes the emergence of new weed flushes $[24,25]$. So, there is a need to review existing methods and evaluate alternative approaches that could be utilized for weed control in organic crop systems [22]. Flame weeding using propane has been proposed as an alternative to these traditional techniques both in organic and conventional agricultural systems [26].

In 1852, flame weeding was first introduced in sugar cane production in the USA. In the mid-1940s, selective flaming was used in many crop productions, including corn, soybeans, alfalfa, cotton, and different fruit and vegetable productions [27].

The greatest challenge in organic row crop production is intra-row weed control [28]. Flaming with cross burner orientation weeds can be controlled in a row of the crop with minimal damage to cultivated crops [15]. The main reason is the distribution of temper- 
atures that are the highest at lower canopy $(<6 \mathrm{~cm}$ tall) that gradually decreased with increase in canopy height [29].

Bearing in mind the fact that practices of thermal methods, e.g., propane flaming, can significantly contribute to weed control on certain surfaces, which, at the same time, affects the results of production in a positive way, made them popular among organic producers since the 1980s. According to previous research, flaming can reduce the dependence on synthetic herbicides, and it can essentially complement mechanical methods of weed control in organic and conventional production [15,30]. In 1990, flame weeding was applied to more than 4000 ha in the USA [31]. The method was also used in maize fields in Germany (totaling 75,000 ha), in the areas where weeds developed resistance to atrazine [32]. Maize is highly tolerant to flaming and can endure two treatments without a significant decrease in yields [33,34].

Propane flaming exposes weeds to heat stress, causing the denaturation of membrane proteins, resulting in a loss of cell function and dehydration, leading to their death or reducing their competition $[21,26]$. Flaming is a transfer of heat from the flame to the plant tissues resulting in boiling water molecules inside the cell [35]. This method leaves no chemical residues in soil, plants, water, or air; does not disturb the soil surface, an does not bring more weed seeds to the soil surface $[19,20]$. Temperatures in the range of 95-100 degrees Celsius can be lethal to weed leaves and stems when applied for at least $0.1 \mathrm{~s}$, which further results in cell desiccation and ultimately the loss of cell function [23].Plant responses to flaming depend on their heat tolerance, protective layers of hair and wax, lignification, and water conditions [36].Weeds are most sensitive to flame heat when they are in the three to the five-leaf stage. Broad-leaf weeds are more susceptible to control with flaming than grasses that are more tolerant to flaming. Ulloa et al. reported a propane dose of about $60 \mathrm{~kg} \mathrm{ha}^{-1}$ whichprovided almost $80 \%$ control of grass weeds and $90 \%$ control of broad-leaf species [37]. Thus, flaming has the potential to be used in crops such as maize (Zea mays L.) and sorghum (Sorghum bicolor [L.] Moench) because these crops have problems with the mentioned weeds, especially in the organic cultivation system, but it can also be used in soybean at the appropriate growth stage [20].

From an economic point of view, the cost of a single flame application emitted under crop canopy could range from 30 to 40USD/ha, not taking into account equipment and labor costs. In comparison, application in the form of layers (over the crop row) for the flame can cost 12-20 USD/ha due to lower propane use rates (30-40 kg/ha) [23]. To be costeffective and sustainable, organic production has to be financially rewarding for individual producers, providing them with a decent living standard. This research's importance is high, having in mind the mentioned restrictions in controlling and suppressing weeds in organic corn production and the fact that weed control costs have a large share in the total cost of crop production. This study aimed to examine the cost-effectiveness of three methods of weed control used in organic maize production: hand weed hoeing accompanied by inter-row cultivation, and two types of flame weeding, one with a prototype flame weeder and the other with the commercial Red Dragon flame weeder [38], and to determine which one of the methods contributes the most to cost savings.

As for this paper's contribution to the literature, this study is even more critical since no economic analysis on flame weeding control used in organic maize production has been conducted in Serbia and only just a few in the world. There are studies of the economic aspects of flame weed control applied in conventional agricultural production, but more knowledge is needed in the field of organic production. For the first time, research was done with a new prototype flame weeder constructed in Serbia [29,39]. The study is expected to provide data for future organic maize producers and other relevant participants. This research aims to indicate the cost-effectiveness of investment in the machinery for intra-row flame weeding in organic maize production to achieve economic sustainability for the household.

The structure of the paper is as follows. The first part (Introduction) lists the primary determinants that are the subject of the paper's research (organic agriculture, sustainability, 
flame weeding). After that, Materials and Methods are presented, explaining the costeffectiveness of three different methods of weed control in corn production. The Results section shows the obtained values for three different models.The obtained results are compared with other research in the Discussions, and recommendations for possible further research in the paper's Conclusion.

\section{Materials and Methods}

Two-year field experiments were established on two locations in Serbia-Rimski

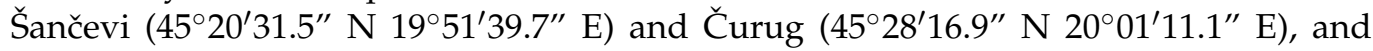
based on the results of this research, all expenses and revenues are determined. The cost-effectiveness of three different methods of weed control in organic maize production was calculated as a comparison of three treatments: (1) intra-row hand hoeing, (2) intra-row flame weeding with a prototype flame weeder $[29,39]$ and (3) intra-row flame weeding with the commercial Red Dragon flame weeder [38].

For this paper, a method of differential calculation was used (Equation (2)). This method is used to determine whether a change in the business of the farm is economically justified.

Analytical calculations were used more often in agriculture. Still, it was shown that they can be unsuitable for agriculture because individual agricultural productions are firmly connected and dependent. It makes no sense to calculate success of individual lines of production but, rather, to calculate the farm's success as a whole. The analytical calculation determines all revenues and all production costs on the farm, their difference (financial result), and the obtained products' cost price. The general scheme of such a calculation is

$$
\mathrm{p}-\mathrm{t}=\mathrm{d}
$$

where $p$ represents the product's market value, $t$ is the sum of all costs, and $d$ is the financial result.

The differential calculation determines only the changes in income and changes in costs resulting from some planned or already taken economic measures on the farm. The general equation of such a calculation is

$$
\Delta \mathrm{U}-\Delta \mathrm{T}=\Delta \mathrm{D}
$$

$\Delta \mathrm{U}$ is the change in the total revenue or the value of a specific production line's production. This instance represents the change in the value of organic maize production caused by the change in yields. $\Delta \mathrm{T}$ is the change in the total costs calculated for each method of weed control. Here, it denotes the difference in the costs of intra-row hand hoeing and flame weeding using two flame weeders. $\Delta \mathrm{D}$ is the change in financial results or economic impacts.

Expenses entail a price valuation of the input costs incurred in producing a good or service [40]. According to Majcen, fees represent the amount of actual labor expressed in monetary terms and the embodiment of work and stipulated contractual and legal obligations required for producing outputs [41].Markovski defines expenses as a valuation of the asset and labor costs incurred, which are constituents of the output cost price [42]. From a broader theoretical perspective, an expense is a valuation of the asset and labor costs incurred in producing a good or service. Such valuation is necessary for finding the common denominator and assessing the financial performance of a business.

The specifics of agriculture, i.e., the process of agricultural production, determine the specificity of costs concerning the costs of other activities. For that reason, when calculating the costs of the agricultural output, the method of standardized costs was applied, which implies a logical verification of the research resultsconcerning the hitherto valid values in the field of research. The starting point for determining these costs was technological operations or agro-technical measures performed in the production of the tested production methods.Thecosts of work operations in various models are calculated based on experiment 
monitoring. Operating costs of different weed control methods were calculated on the basis of the costs of fuel (the price and consumption), maintenance cost, registration, and other title fees, depreciation, and labor. The economic impacts were calculated (per hectare) based on the labor and materials' employed market price. It is noteworthy that the annual net income computed in this paper was based on the data about yields produced in a dry farming system, i.e., in areas without irrigation.

The depreciation, accounting reserve for the equipment and machine replacement, was calculated using time-dependent depreciation Equation (3).

$$
\text { Annual_depreciation_expense }=\mathrm{Vo} / \mathrm{n}
$$

where Vo is the depreciation basis, and $\mathrm{n}$ is the total number of years in use.

The interest costs on the funds invested were included in the Other Costs category.

The maintenance costs were calculated using a normative method based on the total maintenance costs incurred during the equipment's useful life [43]. The method was developed at the KTBL Institute (The KuratoriumfürTechnik und Bauwesen in der Landwirtschafte.V. (KTBL) is a registered association whereagriculture, science, commercial economy, administration and consulting belong. It is institutionally funded by the Federal Ministry of Food and Agriculture. https:/ / www.ktbl.de/wir) and adjusted to the present research. The schedule of the given costs during the equipment's useful life was designed according to the change model in the maintenance and repair costs, also developed at the KTBL Institute [44].

The machinery fuel costs were calculated on the basis of the cost data obtained during the research. These costs were allocated according to the average market price of fuel. The data validation and normalization were performed in comparison with the fuel consumption norms for the standard operating mode of the engine employed [45]. Admittedly, the specific fuel consumption varies considerably depending on the operation method, reaching a minimum at approximately an engine load of $80 \%$. To determine fuel consumption, it is requisite to establish a structure of fuel efficiency and specific fuel consumption. One of the models suitable for determining fuel consumption is a model, according to Renijus [46].

A standard tractor operating mode for low-intensity cultivation was used in this research. The fuel consumption was determined on the basis of the nominal (driving) engine power and the engine load percentage required for a specific operation [46]. Other machinery costs (which mostly include the costs of insurance, storage, oils, lubricants, taxes, and fees) were calculated on the basis of empirical norms for a specific type of machinery.

The income accounting was based on gross income, using Serbian agriculture's average income as a point of reference. All the other costs were allocated based on empirical norms. The application of modern agricultural machinery and implements in crop production encompasses requisite parameters for the optimal exploitation of tractors or engine units [47].

As previously stated, the cost-effectiveness of three different models (or methods) of intra-row weed control in organic maize were assessed in this research, where the first model entailed intra-row hand hoeing in organic maize production, following inter-row cultivation. This method needs a great deal of human labor because weeds have to be eradicated promptly to stop them from competing with the crops for sunlight, water, and soil nutrients.

The second model involved a prototype intra-row flame weeder (Figure 1a), a modified 4-row inter-row cultivator equipped with two $35 \mathrm{~kg}$ propane bottles, gas installations, a pressure regulator, a gas flow meter, and torches. Two torches were mounted on the sides of each cultivator row for intra-row flame weeding, whereas the previously fitted subsoilers and rear sweeps were used for inter-row cultivation $[29,48]$. The prototype was mounted on a $60 \mathrm{~kW}$ tractor. The testing of this prototype in row-crop weed flaming has been conducted since 2010 at the test field RimskiŠančevi (Novi Sad, AP Vojvodina, Serbia) of the Institute of Field and Vegetable Crops Novi Sad. 


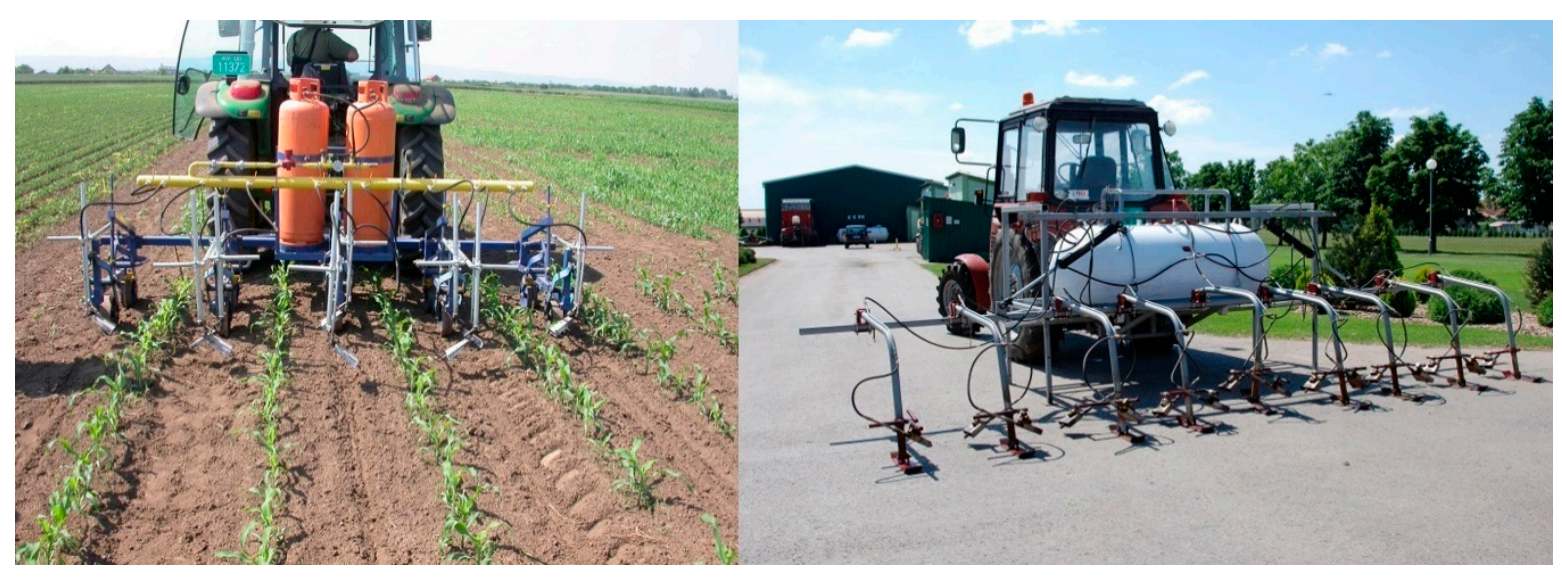

(a)

(b)

Figure 1. (a) The prototype flame weeder for smaller fields designed in Serbia; (b) The commercial Red Dragon flame weeder manufactured by Flame Engineering, Inc., La Crosse, Kansas, USA.

The third model encompassed the use of a commercial Red Dragon flame weeder (Figure 1b), which was mounted on a $90 \mathrm{~kW}$ tractor. The company AD Budućnost has used this machine-Global Seed (Čurug, AP Vojvodina, Serbia) since 2013, accounting for more than 1000 ha of organic maize production [49]. In contrast with the prototype, the Red Dragon flame weeder features an operating width of 8 rows (without inter-row cultivation implements) and an $800 \mathrm{~kg}$ propane tank, which contributes significantly to the overall performance [38].

\section{Results}

In this research, Model 1 entailed hand hoeing, representing the fundamental method of weed control in organic maize production. Under such conditions, the average maize yield was $8.3 \mathrm{t} / \mathrm{ha}$. Daily wages are closely dependent on the extent of weed infestation. For cost accounting, 25 daily wages per single hoeing were taken as an average, i.e., 50 daily wages per two hoeings. The gross wages amounted to $14 €$ per day. Table 1 displays the accounting basis for Model 1.

Table 1. The basic parameters of the cost accounting of Model 1 (hand hoeing), Model 2 (using the prototype flame weeder without (2a) and with (2b) additional hoeing), and Model 3 (using the Red Dragon flame weeder without (3a) and with (3b) additional hoeing).

\begin{tabular}{|c|c|c|c|c|c|c|}
\hline Parameter & Unit of Measurement & (1) & $(2 a)$ & (2b) & (3a) & $(3 b)$ \\
\hline Maize yield & t/ha & 8.3 & 7.8 & 8.3 & 7.8 & 8.3 \\
\hline Working day/hand hoeing/ & days & 50 & 0 & 12 & 0 & 12 \\
\hline Gross wage & $€$ & 14 & 14 & 14 & 14 & 14 \\
\hline Required tractor power & $\mathrm{kw}$ & - & 60 & 60 & 90 & 90 \\
\hline Tractor purchase price & $€$ & & 22,500 & 22,500 & 36,000 & 36,000 \\
\hline Propane consumption & $\mathrm{kg}$ & - & 80 & 80 & 80 & 80 \\
\hline Propane price & $€ / \mathrm{kg}$ & & 1.05 & 1.05 & 1.05 & 1.05 \\
\hline Mounted machine purchase price 01 & $€$ & - & 2400 & 2400 & 19,500 & 19,500 \\
\hline Mounted machine purchase price 02 & $€$ & - & 0 & 0 & 3350 & 3350 \\
\hline Operating width & $\mathrm{m}$ & - & 3 & 3 & 6 & 6 \\
\hline Travel speed & $\mathrm{km} / \mathrm{h}$ & - & 4 & 4 & 4 & 4 \\
\hline Diesel fuel price & $€ / 1$ & & 0.95 & 0.95 & 0.95 & 0.95 \\
\hline Other costs & & & $5.50 \%$ & $5.50 \%$ & $5.50 \%$ & $5.50 \%$ \\
\hline Organic maize price & $€ / \mathrm{kg}$ & 0.20 & 0.20 & 0.20 & 0.20 & 0.20 \\
\hline
\end{tabular}

A comparison of the basic parameters used in the cost accounting of Model 1, 2, and 3 are displayed in Table 1. 
The cost accounting of Model 2 and 3 involved maize yields produced both with and without additional hand hoeing after intra-row flame weeding with the machines tested.

Model 2 included the cost accounting of intra-row flame weeding in organic maize production using the prototype flame weeder. Under such conditions, the average maize yield was $7.8 \mathrm{t} /$ ha without additional hand hoeing (shown as Model 2a in Table 1). Upon a single passage of the prototype flame weeder, two additional hand hoeings can follow, with a forecast of 12 daily wages required, resulting in an average maize yield of $8.3 \mathrm{t} /$ ha (shown as Model $2 \mathrm{~b}$ in Table 1 ). The gross wages also amounted to $14 €$ per day. The prototype flame weeder simultaneously performs intra-row flame weeding and inter-row cultivation. Thus, the costs of inter-row cultivation were excluded from the costaccounting of Model 2. The prototype was mounted on a $60 \mathrm{~kW}$ tractor with a purchase price of $22,500 €$, useful life of 10 years, and an annual depreciation rate of $10 \%$. A diesel fuel price of $0.95 €$ per liter was used in the Model 2 cost accounting. Table 2 shows an overview of the costs of using a $60 \mathrm{~kW}$ tractor.

Table 2. The costs of using a $60 \mathrm{~kW}$ tractor $(€)$.

\begin{tabular}{cccc}
\hline COSTS & TOTAL & \% & Per Hour of Use \\
\hline Fixed assets depreciation & 2250.00 & 24.71 & 2.50 \\
Interest costs & 680.63 & 7.48 & 0.76 \\
Maintenance costs & 918.00 & 10.08 & 1.02 \\
Fuel costs & 4655.73 & 51.14 & 5.17 \\
Other costs & 600.00 & 6.59 & 0.67 \\
TOTAL & 9104.35 & 100.00 & 10.12 \\
\hline
\end{tabular}

The propane consumption amounted to $80 \mathrm{~kg}$ per two machine passages, which are required for a single production cycle. The propane price was $1.05 € / \mathrm{kg}$. The mounted machine's purchase price was $2400 €$, the travel speed was $4 \mathrm{~km} / \mathrm{h}$, and the operating width was $3 \mathrm{~m}$. Table 3 displays an overview of the costs of using the prototype flame weeder.

Table 3. The costs of using the prototype flame weeder $(€)$.

\begin{tabular}{cccc}
\hline COSTS & TOTAL & $\%$ & Per Hour of Use \\
\hline Fixed assets depreciation & 240.00 & 49.48 & 0.80 \\
Interest costs & 72.60 & 14.97 & 0.24 \\
Maintenance costs & 122.40 & 25.24 & 0.41 \\
Other costs & 50.00 & 10.31 & 0.17 \\
TOTAL & 485.00 & 100.00 & 1.62 \\
\hline
\end{tabular}

The cost accounting of Model 3 included the costs of using the commercial Red Dragon flame weeder. The average maize yield was $7.8 \mathrm{t} /$ ha without additional hand hoeing (shown as Model 3a in Table 1). Upon a single passage of the Red Dragon flame weeder, two additional hand hoeings can follow, with a forecast of 12 daily wages required, amounting gross to $14 €$ per day (shown as Model $3 \mathrm{~b}$ in Table 1 ). The use of the Red Dragon flame weeder also required additional inter-row cultivation, the costs of which were included in Model 3a and Model 3b. The Red Dragon flame weeder was mounted on a $90 \mathrm{~kW}$ tractor with a purchase price of 36,000 $€$, useful life of 10 years, and an annual depreciation rate of $10 \%$. A diesel fuel price of $0.95 €$ per liter and an interest rate of $5.5 \%$ were used in the Model 3 cost accounting. Table 4 shows an overview of the costs of using a $90 \mathrm{~kW}$ tractor. 
Table 4. The costs of using a $90 \mathrm{~kW}$ tractor $(€)$.

\begin{tabular}{cccc}
\hline COSTS & TOTAL & \% & Per Hour of Use \\
\hline Fixed assets depreciation & 3600.00 & 21.26 & 3.00 \\
Interest costs & 1089.00 & 6.43 & 0.91 \\
Maintenance costs & 1836.00 & 10.84 & 1.53 \\
Fuel costs & 9311.45 & 54.98 & 7.76 \\
Other costs & 1100.00 & 6.49 & 0.92 \\
TOTAL & $16,936.45$ & 100.00 & 14.11 \\
\hline
\end{tabular}

The propane consumption amounted to $80 \mathrm{~kg}$ per two passages of the Red Dragon machine (the same as in the prototype application). The propane price was $1.05 € / \mathrm{kg}$. The mounted machine's purchase price was $22,850 €$, the travel speed was $4 \mathrm{~km} / \mathrm{h}$, and the operating width was $6 \mathrm{~m}$. Table 5 displays an overview of the costs of using the Red Dragon flame weeder.

Table 5. The costs of using the Red Dragon flame weeder $(€)$.

\begin{tabular}{cccc}
\hline COSTS & TOTAL & $\%$ & Per Hour of Use \\
\hline Fixed assets depreciation & 2285.00 & 65.43 & 7.62 \\
Interest costs & 691.21 & 19.79 & 2.30 \\
Maintenance costs & 466.14 & 13.35 & 1.55 \\
Other costs & 50.00 & 1.43 & 0.17 \\
TOTAL & 3492.35 & 100.00 & 11.64 \\
\hline
\end{tabular}

Based on previous research and using various methods, most commonly work process recording [40], a working time in crop production was established. The structure used in the cost accounting performed herein is shown in Figure 2.

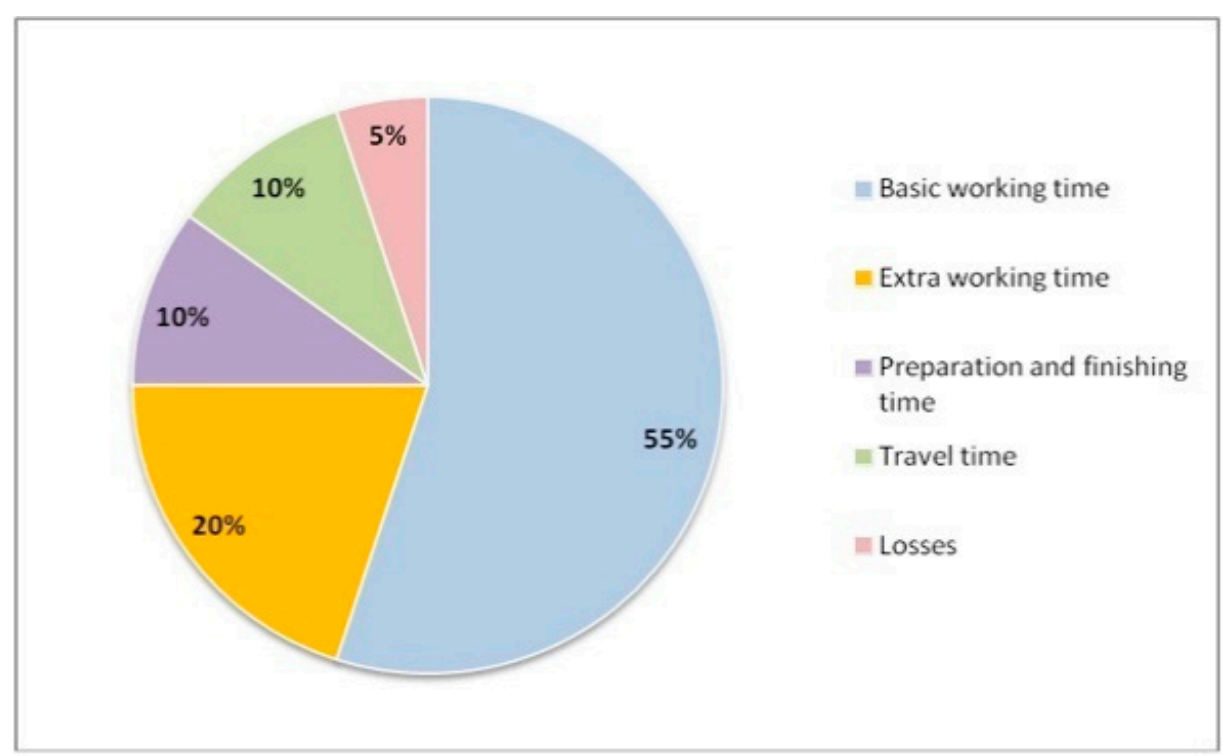

Figure 2. The structure of working time.

The price of organic maize varies according to the demand and supply in the market. On average, it is $30 \%$ higher than the cost of conventional corn kernels. A price of $0.20 € / \mathrm{kg}$, established in the Fruit and Vegetable Market of Bologna [50], was used in the differential calculations of Model 1, 2, and 3 (Table 6). 
Table 6. The differential calculations of Model 1 (hand hoeing), Model 2 (using the prototype flame weeder without (2a) and with (2b) additional hoeing) and Model 3 (using the Red Dragon flame weeder without (3a) and with (3b) additional hoeing).

\begin{tabular}{ccccccc}
\hline Parameter & Unit of Measurement & $\mathbf{( 1 )}$ & $\mathbf{( 2 a )}$ & $\mathbf{( 2 b )}$ & $\mathbf{( 3 a )}$ & $\mathbf{( 3 b )}$ \\
\hline Yield & $\mathrm{t} / \mathrm{ha}$ & 8.3 & 7.8 & 8.3 & 7.8 & 8.3 \\
Selling price & $€ / \mathrm{kg}$ & 0.20 & 0.20 & 0.20 & 0.20 & 0.20 \\
Revenue & $€ / \mathrm{ha}$ & 1660.00 & 1560.00 & 1660.00 & 1560.00 & 1660.00 \\
Revenue change & $€ / \mathrm{ha}$ & 0.00 & -100.00 & 0.00 & -100.00 & 0.00 \\
Operating cost & $€ / \mathrm{ha}$ & 729.26 & 139.87 & 307.87 & 172.79 & 340.79 \\
Expense change & $€ / \mathrm{ha}$ & 0.00 & 589.39 & 421.39 & 556.47 & 388.47 \\
Economic impact & $€ / \mathrm{ha}$ & 0.00 & 489.39 & 421.39 & 456.47 & 388.47 \\
\hline
\end{tabular}

To achieve optimum or maximum economic results, the efficiency of a flame weeder application should be considered [51,52]. Should intra-row flame weeding be applied at the V3-V4 and V6-V7 stages of maize growth, using propane (40 kg/ha) in combination with inter-row cultivation, a total of $90-95 \%$ of weeds could be eradicated, resulting in a yield of $7.8 \mathrm{t} / \mathrm{ha}$ (compared to a yield of $8.3 \mathrm{t} / \mathrm{ha}$ in the hand-hoed control field). A decrease in yields is not a consequence of the flaming damage but of the persistence of weeds to endure the treatment.

The cost accounting performed indicated a decrease in the costs per hectare when the prototype flame weeder and the commercial Red Dragon flame weeder were used compared to hand hoeing. However, greater cost savings, were recorded when the prototype flame weeder was used (489.39 $€ /$ ha in Model 2a) than in the application of the Red Dragon flame weeder (456.47 €/ha in Model 3a). If we look at Model 2 in particular, the comparison of yields shows that hand hoeing's introduction achieves a difference in yields of $500 \mathrm{~kg}$ ( $8300 \mathrm{~kg}$ for $2 \mathrm{~b}, 7800 \mathrm{~kg}$ for $2 \mathrm{a}$ ). At the same time, additional income of $100 € /$ ha (1660 for $2 b, 1650$ for $2 a$ ) is realized, while additional costs are $168 € /$ ha ( 307.87 for $2 \mathrm{~b}, 139.87$ for $2 \mathrm{a}$ ). Given that in this case, the marginal cost exceeds the marginal revenue, investments in additional hand hoeing are not economically justified.

\section{Discussion}

These results are consistent with Nemming [50], who also proved the cost-effectiveness of flame-weeding machinery in organic agricultural production compared to hand weed hoeing [51]. A flame weeder can be constructed more cost-effectively by modifying an existing cultivator. However, such a machine ought to be applied to an area of 6-20 ha to justify the investments [51].

To be cost-effective and sustainable, organic production has to be financially rewarding for individual producers, providing them with a decent living standard. The study's objective was to investigate the cost-effectiveness of three different weed control methods used in organic maize production and determine the best solution economically. From the individual producer's perspective, weed control is one of the significant issues in organic agriculture. Due to a ban on the use of chemical agents, organic producers are faced with a limited choice of weed control methods, resulting commonly in the use of poorly cost-effective hand hoeing.

\section{Conclusions}

Following a comparative analysis of hand weed hoeing, the use of Prototype Flame Weeder and Red Dragon flame weeder is economically justified in reducing labor costs of weed control in organic maize production. The prototype flame weeder contributed to a significant cost reduction per unit of area, approximating $490 € /$ ha per hectare. Moreover, the analysis has also shown that additional hand hoeing investments are not economically justified because the operating costs incurred therein $(168 € /$ ha) were not met by a yield increase of $500 \mathrm{~kg} / \mathrm{ha}$, i.e., a surplus revenue of $100 € /$ ha. The high price and limited efficacy of both the prototype and Red Dragon flame weeder render this method more 
expensive than the application of herbicides in conventional production. Conversely, flame weeding is economically justified in organic production due to high labor costs. Labor costs are very high in organic production. They are of immense importance to organic farms' financial results, especially in plant production. On average, such prices are from 8 to $25 \%$ higher than the labor costs incurred in conventional maize production. Flame weeding can substantially reduce labor costs in organic farming and, therefore, the total production cost.

Additionally, the economic impacts of flame weeding would be considerably more significant in larger fields. However, the cost reduction recorded in smaller fields can affect the overall financial results of organic farms, which contributes to the economic sustainability of organic farming.

Although this study confirmed and justified the use of flame weeding in weed control in organic maize production, it is necessary to extend the research to other crops that are most commonly grown in the organic system and whose weed control costs are high. Moreover, given the small number of studies conducted so far with the prototype, it would be desirable to repeat the research in different natural conditions.Given the importance of organic farming for sustainable development, development policies should pay more attention to this production system. Introducing producers who are already in the organic production system with ways to improve their economic sustainability, the introduction of new production technologies, such as flame weeding, can be achieved through various forms of informal education that can be organized by local governments.

Author Contributions: Conceptualization and methodology, M.R. and G.M.; software, M.T.S.; validation, D.G.-T.; data curation, D.M.; writing—original draft preparation, M.R. and M.T.S.; writingreview and editing, M.M.; supervision, S.V. All authors have read and agree to the published version of the manuscript.

Funding: This research was supported by the Ministry of Education, Science and Technological Development of the Republic of Serbia, grant number 451-03-68/2020-14/200032 and 451-03-68/2020$14 / 200117$.

Institutional Review Board Statement: Not applicable.

Informed Consent Statement: Not applicable.

Data Availability Statement: No new data were created or analyzed in this study. Data sharing is not applicable to this article.

Conflicts of Interest: The authors declare no conflict of interest.

\section{References}

1. Kovačević, D.; Lazić, B.; Milić, V. The Effects of Agriculture on Environment. In Proceedings of the International Scientific Symposium of Agriculture “Agrosym Jahorina 2011”, Jahorina, Bosnia and Herzegovina, 10-12 November 2011; pp. 34-47. Available online: http://agrosym.ues.rs.ba/agrosym/agrosym_2011/pdf/Plenary_lectures/Kovacevic_D_et_al.pdf (accessed on 21 April 2019).

2. Hodge, I. Sustainability: Putting Principles into Practice. In An Application to Agricultural Systems, Paper Presented to Rural Economy and Society Study Group; Royal Holloway College: Egham, UK, 1993.

3. Rodriguez, E.; Sultan, R.; Hilliker, A. Negative Effects of Agriculture on Our Environment. Eff. Agric. Traprock 2004, 3, $28-32$.

4. Praneetvatakul, S.; Schreinemachers, P.; Pananurak, P.; Tipraqsa, P. Pesticides, external costs and policy options for Thai agriculture. Environ. Sci. Policy 2013, 27, 103-113. [CrossRef]

5. Krajewski, P. Agricultural Biodiversity for Sustainable Development. Probl. Sustain. Dev. 2016, 12, $135-141$.

6. Lampkin, N.; Padel, S. The Economics of Organic Farming: An International Perspective; University of Wales: Aberystwyth, UK; CABInternational: Oxford, UK, 1994; p. 467.

7. Tomaš-Simin, M.; Janković, D. Applicability of diffusion of innovation theory in organic agriculture. Econ. Agric. 2014, 61, 517-529. [CrossRef]

8. Mccann, E.; Sullivan, S.; Erickson, D.; DeYoung, R. Environmental Awareness, Economic Orientation, and Farming Practices: A Comparison of Organic and Conventional farmers. Environ. Manag. 1997, 21, 747-758. [CrossRef]

9. Patil, S.; Reidsma, P.; Shah, P.; Purushothaman, S.; Wolf, J. Comparing conventional and organic agriculture in Karnataka, India: Where and when can organic farming be sustainable? Land Use Policy 2014, 37, 40-51. [CrossRef]

10. Pimentel, D. Economics and energetic of organic and conventional farming. JAGR Environ. Ethic 1993, 6, 53-60. [CrossRef] 
11. Darnhofer, I.; Schneeberger, W.; Freyer, B. Converting or not converting to organic farming in Austria: Farmer types and their rationale. Agric. Hum. Values 2005, 22, 39-52. [CrossRef]

12. Brenes-Muñoz, T.; Lakner, S.; Brümmer, B. What Influences the Growth of Organic Farms? Evidence from a Panel of Organic Farms in Germany. Ger. J. Agric. Econ. 2016, 65, 1-15. [CrossRef]

13. Läpple, D.; Kelley, H. Understanding the uptake of organic farming: Accounting for heterogeneities among Irish farmers. Ecol. Econ. 2013, 88, 11-19. [CrossRef]

14. Oerke, E.C.; Dehne, H.W.; Schonbeck, F.; Weber, A. Crop Production and Crop Protection: Estimated Losses in Major Food and Cash Crops, 1st ed.; ElsevierScience: Amsterdam, The Netherlands, 1994; p. 808. ISBN 9780444597946.

15. Stepanovic, S.; Datta, A.; Neilson, B.; Bruening, C.; Shapiro, C.A.; Gogos, G.; Knezevic, S.Z. Effectiveness of flame weeding and cultivation for weed control in organi cmaize. Biol. Agric. Hortic 2015, 32, 47-62. [CrossRef]

16. Bond, W.; Turner, R.; Grundy, A. A Review of Non-Chemical Weed Management; Technical Report; HDRA, Ryton Organic Gardens: Coventry, UK; HRI: Wellesbourne, UK, 2003; Available online: https:/ / gardenorganic.org.uk/sites/www.gardenorganic.org.uk/ files/updated_review_0.pdf (accessed on 2 May 2019)Technical Report.

17. Barberi, P. Weed management in organic agriculture: Are we addressing the right issues? Weed Res. 2002, 42, 177-193. [CrossRef]

18. Pannacci, E. Optimization of for am sulfur on doses for post-emergence weed control in maize (ZeamaysL.). Span. J. Agric. Res. 2016, 14, 1005. [CrossRef]

19. Loni, R.; Loghavi, M.; Jafari, A. Design, Development and Evaluation of Targeted Discrete-Flame Weeding for Inter-row Weed Control Using Machine Vision. Am. J. Agric. Sci. Technol. 2014, 2, 17-30. [CrossRef]

20. Stepanovic, S.; Datta, A.; Neilson, B.; Bruening, C.; Shapiro, C.; Gogos, G.; Knezevic, S. The effectiveness of flame weeding and cultivation on weed control, yield and yield components of organic soybean as influenced by manure application. Renew. Agric. Food Syst. 2015, 31, 288-299. [CrossRef]

21. Datta, A.; Knezevic, S.Z. Flaming as an Alternative Weed Control Method for Conventional and Organic Agronomic Crop Production Systems: A Review. Adv. Agron. 2013, 118, 399-428. [CrossRef]

22. Kruidhof, H.; Bastiaans, 1.; Kropff, M. Ecological weed management by cover cropping: Effects on weed growth in autumn and weed establishment in spring. Weed Res. 2008, 48, 492-502. [CrossRef]

23. Knezevic, S.Z. Flame Weeding in Corn, Soybean and Sunflower. In Proceedings of the 8th International Conference of Information and Communication Technologies in Agriculture, Food and Environment (HAICTA 2017), Chania, Greece, 21-24 September 2017; pp. 390-394.

24. Wszelaki, A.L.; Doohan, D.J.; Alexandrou, A. Weed control and crop quality in cabbage [Brassica oleracea (capitatagroup)] and tomato (Lycopersiconly copersicum) using a propane flamer. Crop. Prot. 2007, 26, 134-144. [CrossRef]

25. Ulloa, S.; Datta, A.; Malidza, G.; Leskovsek, R.; Knezevic, S. Timing and propane dose of broad cast flaming to control weed population influenced yield of sweet maize (Zea mays L.var.rugosa). Field Crop. Res. 2010, 118, 282-288. [CrossRef]

26. Abou Chehade, L.; Fontanelli, M.; Martelloni, L.; Frasconi, C.; Raffaelli, M.; Peruzzi, A. Effects of flame weeding on organic garlic production. Horttechnology 2018, 28, 502-508. [CrossRef]

27. Lague, C.; Gill, J.; Lehoux, N.; Peloquin, G. Engineering performances of propane flamers used for weed, insect pest, and plant disease control. Appl. Eng. Agric. 1997, 13, 7-16. [CrossRef]

28. Van Der Weide, R.Y.; Bleeker, P.O.; Achten, V.T.; Lotz, L.A.; Fogelberg, F.; Melander, B. Innovation in mechanical weed control in crop rows. Weed Res. 2008, 48, 215-224. [CrossRef]

29. Rajković, M.; Malidža, G.; Stepanović, S.; Kostić, M.; Petrović, K.; Urošević, M.; Vrbničanin, S. Influence of Burner Position on Temperature Distribution in Soybean Flaming. Agronomy 2020, 10, 391. [CrossRef]

30. Bond, W.; Grundy, A.C. Non-chemical weed management in organic farming systems. Weed Res. 2001, 41, 383-405. [CrossRef]

31. Melander, B.; Rasmussen, I.A.; Bàrberi, P. Integrating physical and cultural methods of weed control - examples from European research. Weed Sci. 2005, 53, 369-381. [CrossRef]

32. Hoffmann, M. New Experiences in Thermal Treatment of Indian Corn and Potatoes. In Proceedings of the Third International Conference on Non-Chemical Weed Control, Linz, Austria, 5 October 1990; pp. 19-25.

33. Knezevic, S.; Ulloa, S. Potential new tool for weed control in organically grown agronomic crops. J. Agric. Sci. 2007, 52, 95-104. [CrossRef]

34. Knezevic, S.Z.; Datta, A.; Bruening, C.; Gogos, G.; Stepanovic, S.; Neilson, B.; Nedeljkovic, D. Propane-Fueled Flame Weeding in Corn, Soybean, and Sunflower; University of Nebraska: Lincoln, NE, USA, 2012; pp. 1-32.

35. Lague, C.; Gill, J.; Peloquin, G. Thermal Controlin Plant Protection. In Physical Control Methods in Plant Protection; Vincent, C., Panneton, B., Fleurat-Lessard, F., Eds.; Springer: Berlin, Germany, 2001; pp. 35-46.

36. Ascard, J. Effects of flame weeding on weed species at different developmental stages. Weed Res. 1995, 35, 397-411. [CrossRef]

37. Ulloa, S.M.; Datta, A.; Knezevic, S.Z. Growth stage influenced differential response of foxtail and pig weed species to broadcast flaming. Weed Technol. 2010, 24, 319-325. [CrossRef]

38. Flame Engineering: Row Crop Flamer Red Dragon. Available online: https://flameengineering.com/products/red-dragon-rowcrop-flamers (accessed on 1 May 2020).

39. Rajković, M.; Malidža, G.; Kostić, M.; Petrović, K.; Tančić Živanov, S.; Pavlović, D.; Vrbničanin, S. Flame Cultivator, MP-2019/25, Reg.no.1632, Petty Patents, Intellectual Property Gazette 11/2019, p. 56. Available online: http://www.zis.gov.rs/upload/ documents/pdf_sr/pdf/glasnik/GIS_2019/Glasnik_11_2019.pdf (accessed on 28 November 2019). 
40. Krmpotić, T.; Nikolić, R.; Kiš, T.; Ivančević, S.; Cilger, M.; Jerinkić, E.; Gligorić, R. Menadžment Poljoprivrednih Mašina, 1st ed.; Univerzitet u Novom Sadu, Ekonomski fakultet: Subotica, Srbija, 1997; pp. 1-374.

41. Majcen, Ž. Troškovi u teoriji i praksi, 4th ed.; Informator: Zagreb, Hrvatska, 1988; pp. 292-293.

42. Markovski, S. Troškovi u Poslovnom odlučivanju, 1st ed.; Naučna knjiga: Beograd, Srbija, 1991; pp. 1-342.

43. Funk, M. KTBL-Taschenbuch Landwirtschaft; KTBL: Darmstadt, Germany, 1996; pp. 1-275.

44. Schmid, A. Wirtschaftliche Betriebsführung und Kalkulationim Lohnunternehmen; KTBL: Darmstadt, Germany, 1995; pp. 1-247.

45. Nikolić, R.; Furman, T.; Gligorić, R.; Popović, Z.; Oparnica, S.; Savin, L. Potrošnja dizel Goriva u Ratarstvu, 1st ed.; Univerzitet u Novom Sadu, Poljoprivredni fakultet, Institut za poljoprivrednu tehniku: Novi Sad, Srbija, 1995; pp. 1-113.

46. Renijus, K. Traktoren-Technik und ihre Anwendung, 2nd ed.; Verlagsunion-Agrag, Verlagsgesellschaft, BVL: Múnchen, Germany, 1985; pp. 1-230.

47. Ružičić, L.N.; Petrović, P.; Gligorević, K.; Oljača, M.; Ružičić, T. Ekonomsko-tehnološki parametric optimalnog korišćenja traktora (Economic and Technological Parameters for Optimal Use of Tractors). Agro-Know. J. 2012, 13, 259-266. [CrossRef]

48. Rajković, M.; Malidža, G.; Gvozdenović, Đ.; Vasić, M.; Gvozdanović-Varga, J. Susceptibility of bean and pepper to flame weeding. Acta Herbol. 2011, 19, 67-76.

49. Global Seed. Available online: http:/ / www.globalseed.info (accessed on 1 May 2020).

50. La Borsa Merci Di Bologna. Available online: http:/ / www.agerborsamerci.it (accessed on 3 May 2020).

51. Nemming, A. Costs of flame cultivation. Acta Hortic. 1994, 372, 205-212. [CrossRef]

52. Teodinov, D.; Bošnjak, D.; Radojičić, N. Possibilities for improving sugar beet sowing process using the time study analysis. Field Veg. Crop. Res. 2012, 49, 208-213. 